\section{Tasty blueberries? Not this time}

\section{Everything about poisonous plants in Polish gardens and forests}

Krzysztof Bukowski, Irmina Wojciechowska

\section{Summary:}

DOI: $10.24131 / 3247.170101$

Among the plant species occuring naturally in Poland, apart from edible and completely harmless to humans, there are also poisonous ones. Without specific knowledge it is not easy to recognize and distinguish them. To make it even more difficult, those plants are able to develop visually tempting fruits. Such species are the topic of this article.

Plants are toxic due to the poisons they contain. Toxicity is therefore a natural method of defense against being eaten, which directly affects the survivability of species. Sometimes slight contact with a toxic plant is enough to feel detrimental consequences. In terms of the structure, toxins belong to various organic compound groups, e.g. glycosides, alkaloids or they can be derivatives of certain organic compounds. Some of them are harmful even in tiny amounts, like in a yew's case, others- in small doses are herbal medicines known for centuries (as black elder or lily of the valley) and wreak havoc in human organisms after overdosing.

Key words: phytotoxins, poisonous plants in Poland, biologically active substances

received: 15.11.2016; accepted: 27.12.2016; published: 18.04.2017

Krzysztof Bukowski: Faculty of Chemical Technology University of Technology in Poznań

Irmina Wojciechowska, B.Sc., Eng.: Faculty of Chemica Technology University of Technology in Poznań

\section{Introduction}

Summer, like no other season of the year, inclines to excursions in the bosom of nature. While travelling the length and breath of Poland, we meet countless number of fauna and flora species. We would rather expect that a walk through the woods or a visit to the city park does not carry any risk. The chance that we meet any predators or poisonous animals on our way is negligible. Plants are rarely identified as a potential danger. They draw our attention by their attractive appearance, color and smell. The society in general is not aware of the threats to the health and life resulting from the accidental contact with toxins contained therein.

First of all we should ask ourselves why plants produce toxic substances. Well, the production of toxins is just one of the defense mechanisms against herbivores. Plants in the course of evolution have developed different ways allowing deterring herbivores. They required adoption of their external structure and physiology.

Defense mechanisms of plants can be divided into mechanical/physical (for instance spines and thorns) and chemical (which are the subjects of our interest in this article). Chemical defense mechanisms are responsible for the synthesis and storage of certain organic compounds produced in the specific metabolic pathways. These are the so-called secondary metabolites, whose name originates from the fact that they are not essential for growth and development, but they have many other applications. They serve to deter herbivores (repellents), e.g. by giving unpleasant odor or taste to vegetable tissues or irritating alimentary tract after their consumption (Mazid 2011). Secondary metabolites can belong to any group of organic compounds, but these are most often alkaloids (basic nitrogen-containing organic compounds) and glycosides (carbohydrate derivatives containing a non-sugar group).

The construction of toxins and their location in plant tissues differs. The possibility of accidental contact with the toxin through the skin or ingestion explains why small children and pets that are the most vulnerable to poisoning, although it happens that the victims of plant toxins are also adults by their carelessness or lack of knowledge about the collected herbs or fruit. Consumption of parts of toxic plant results in specific symptoms shown by internal organs and usually involves gastrointestinal, respiratory and nervous systems. Dermal exposure to toxic compounds leads to burns, skin allergies and irritation. In extreme cases, poisoning by plant toxins can also lead to death, especially if respiratory and nervous systems are damaged.

Hereinafter we are going to present a number of poisonous berries commonly found in gardens, parks and roadless tracks across Poland. Common characteristics to the selected plants is their prevalence in the territory of Poland and ability to produce fruit in the form of berries, as well as the presence of compounds harmful and toxic to human being in their tissues.

\section{English/European yew}

English/European yew, Taxus baccata, is an evergreen conifer, famous for its longevity (Fig. 1); we have heard of 100-year old individual specimen. It is rare in Poland (just in a little bit more than 200 stations); however it takes a large area, mostly in the mountains. 
The yew stock is falling down partly due to harvesting wood prized especially for hardness. This happens even though yew is formally under protection since the statute issued in 1423 by Wladyslaw Jagiello (!) (PiękośMirkowa, Mirek, 2003). Despite fading number of yew positions in forest areas, it is often present in parks and home gardens because of its decorative properties. Noteworthy are its characteristic red, cuplike arils surrounding the seeds. Arils, as the only part of the plant, do not contain taxin, a poisonous alkaloid, although the seeds inside are highly toxic (Bryan-Brown, 1932). The mechanism of action of taxin on the human body is not fully known. It probably involves the system of sodiumcalcium management (Thuret-Carnahan, 1985) and blocking mitosis and meiosis by interfering with the process of forming the karyokinetic spindle). Anyway, we know that it has the greatest impact on the heart and liver.

First symptoms of poisoning occur after approx. 1-2 hours after ingestion and begin with heart disorders resulting from the problems with the electric conduction system and consequently too low or too high heart rate. They followed by symptoms associated with the alimentary system: abdominal pain, diarrhea and vomit-

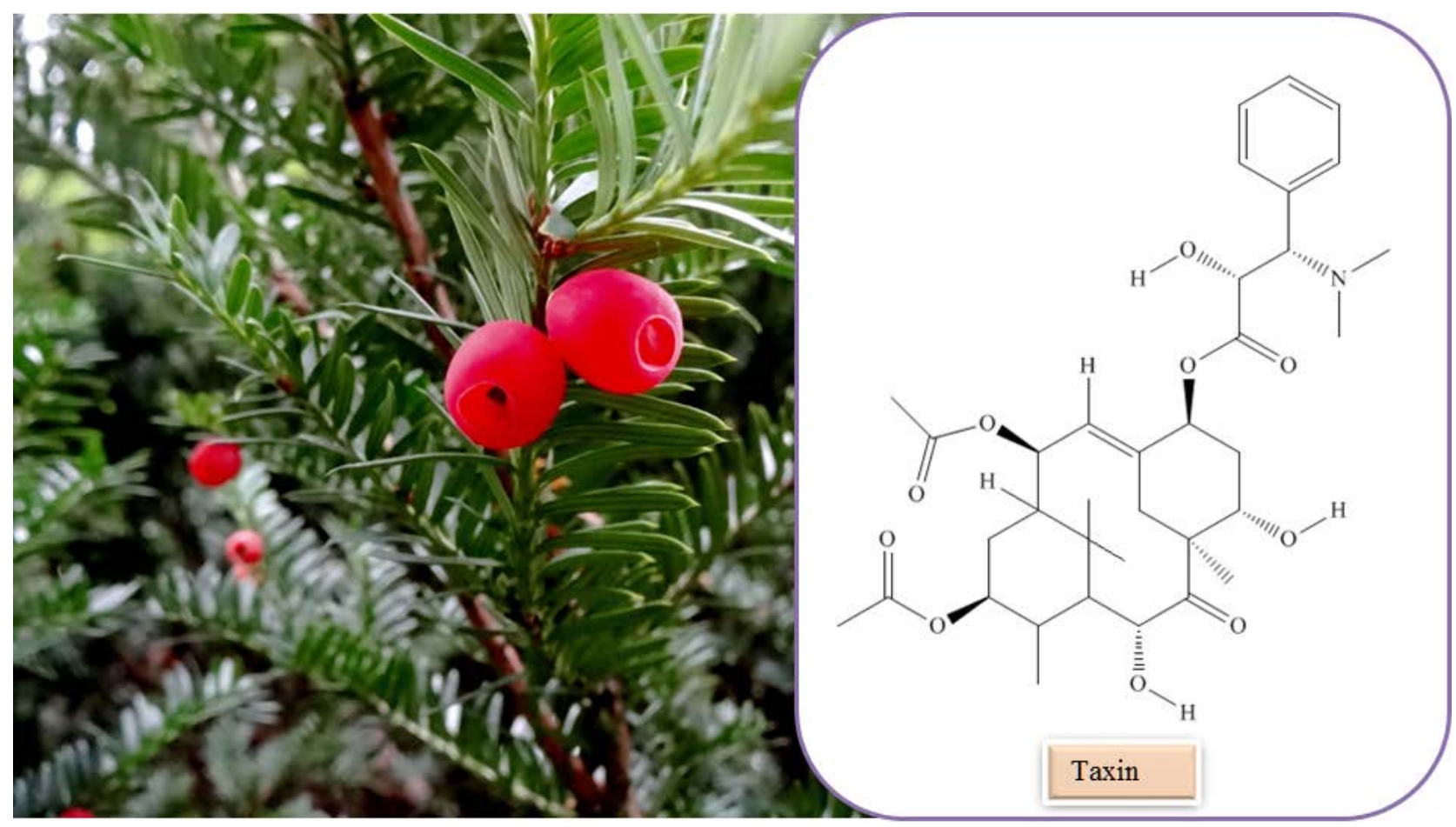

Fig. 1. English/European yew

English ivy, Hedera helix L., (Fig. 2) is an evergreen vine with leaves with distinctive, triangular flaps. ing (Kobusiak-Prokopovich et al., 2016). Damage to the circulatory system can cause disorders in the nervous system, such as aphasia (loss of speech), weakness, and paralysis of the respiratory center. Death may occur due to hypoxia or circulatory arrest (Wilson, 2000).

For many centuries ivy has had a symbolic and religious meaning. As an evergreen it was symbolizing eternity and immortality. An ivy wreath was originally used to decorate poets in Greece, and only later was replaced by laurels. Moreover, these same Greeks and then the Romans adorned wine gods - Dionysus and Bacchus. It was even believed that it has magical properties allowing to separate wine from water (PiękośMirkowa, Mirek, 2003).

\section{Hedera helix}

Hedera helix is also interesting in the chemical point of view because it contains a lot of organic compounds, such as saponins, phenols, alkaloids and organic acids (Sarva, 2001). Brew made of it has been known for years for its healing properties (mainly to the upper respiratory tract as it is a relaxant to smooth muscle). The extract is used in anti-cellulite cosmetics due to the presence of saponins that lower surface tension, break down fat and improve skin absorption (Sainio, 2001). However, some chemicals contained in ivy are toxic. Its blueblack fruit resembles a blueberry, but contrary to it, it not suitable for consumption. It is hard and extremely bitter and contain a high concentration of terpene saponin ( $\alpha$-hederin and hederakoside $C$ ) in which the nonsugars part is hederagenin. Consumption of more ivy fruits causes digestive (diarrhea and vomiting) and nervous (hallucinations, impaired consciousness) issues. In turn, contact with the damaged plant tissue may cause skin irritation by allergen containing falcarinol, alcohol having some anti-tumor properties (Burda, 1998). 


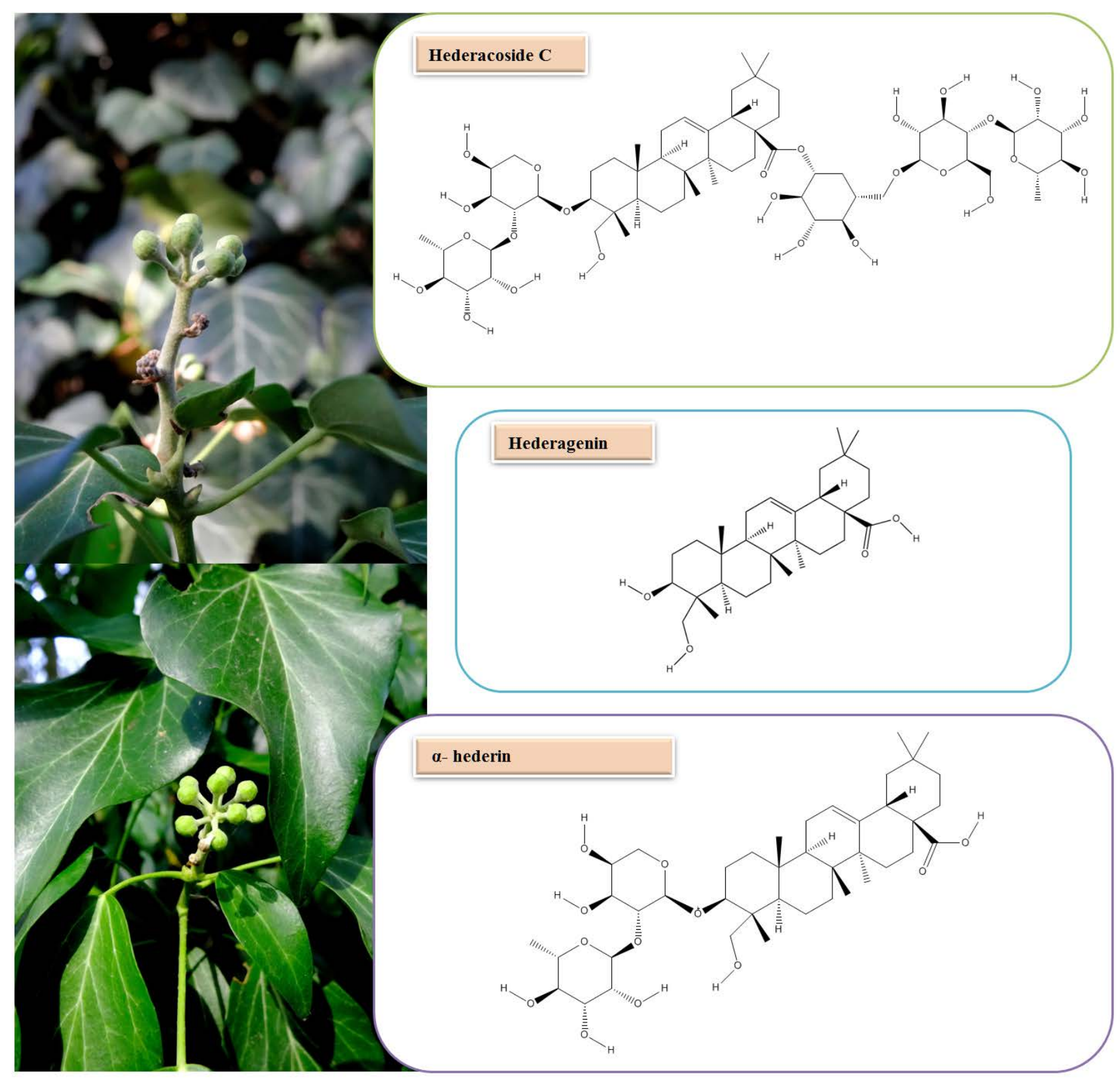

Fig. 2. English ivy

\section{Wild elderberry}

Wild elderberry, Sambucus nigra, popularly known in Poland as 'hyćka', is a shrub having no special soil requirements, common in the meadows, roadless areas or across forest paths (Fig. 3). Its characteristic black berries gathered in pendulous umbels are dainty of birds. They are also recognized as extremely useful in folk medicine and folklore (Atkinson, 2002).

At the time of the Druids elderberry bush was a holy tree. It was believed that any injury done to the brush would bring misfortune to the home of a man who misbehaved towards the sanctity of this plant (Ziółkowska, 1988). This was reflected in the fairy tale of Hans Christian Andersen "Elder-Mother" (http://www.andersen. sdu.dk). In addition, it was believed that a short nap un-

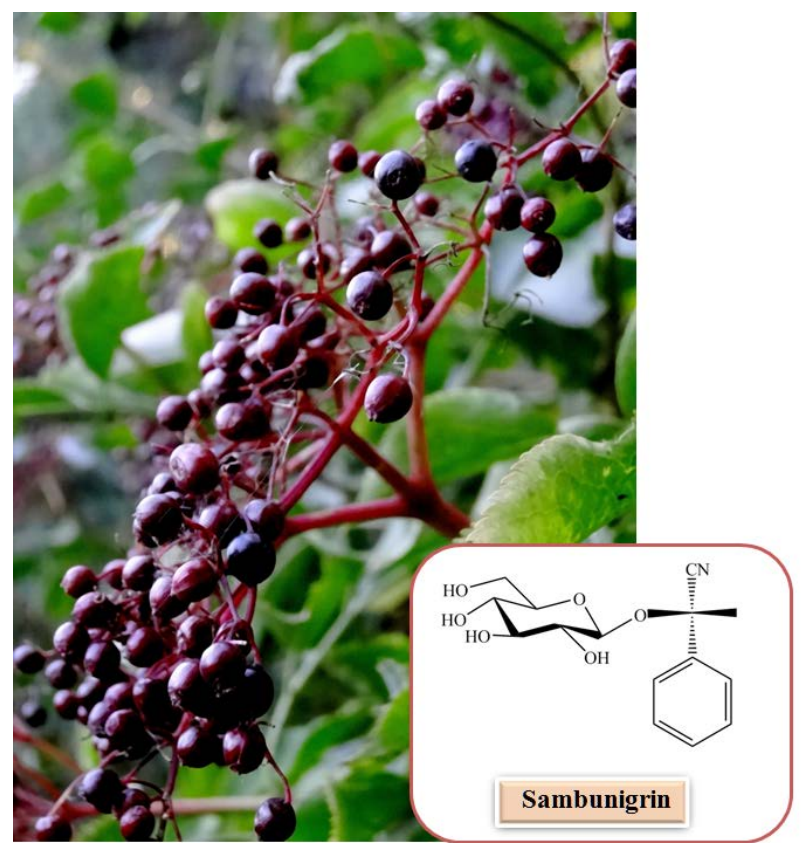

Fig. 3. Wild elderberry 
der an elderberry bush leads straight to a meeting with the King of the Elves, and we can easily guess that hardly anyone escaped with his life in such event. Also J.K. Rowling, author of the Harry Potter books, knew the magical nature of this tree making elderberry wands most powerful.

The times of Christian culture were not favourable for this shrub. Elderberry was dethroned along with pagan deities as supposedly constituted building material of Jesus' cross. Also Judas Iscariot hanged himself on the elderberry bush (Grieve, 1931).

This bad reputation has not affected, however, the recognized position of elderberry in folk medicine. Nowadays juice made of elderberry fruit is a wellknown remedy against colds, flu, cough, throat pain, inflammation and rheumatism. It is believed in Silesia that the branches of elderberry thrown into the pigsty would protect pigs from any plague. Root extract was once used for dying hair to tarry color and flower umbels fried in batter were quite a dainty for young and old. Flowers consumed on the St. John eve day (or perhaps on Pagan Sobótka) had to provide health for the following year (Ziółkowska, 1988).

Elderberry fruit is suitable for consumption after prior heat treatment. Berries can fried or cooked, and preserves of them taste perfectly seasoned with honey and lemon. Eating fruit straight from the bush or drink raw juice is not recommended as it can lead to poisoning, manifested by nausea and problems with the digestive system, dizziness, circulatory problems and even loss of consciousness.

The most important alkaloids of elderberry are sambucinum and sambunigrin. Sambucinum is an alkaloid with laxatives properties and does not constitute a threat to human health. Sambunigrin in turn belongs to the group of cyanogenic glycosides (Braun, 2015). This means that the molecule of the compound is made up of two, sugar- and cyanohydrin parts. As a result of the destruction of the cellular structure of the plant tissue during digestion, cyanogenic glycosides previously stored in the vacuoles are hydrolyzed, and the resulting cyanohydrin is reduced to ketone derivative with the release of hydrogen cyanide molecules, i.e. prussic acid. It is responsible for the toxic effects observed after the consumption of immature and thermally unprocessed elderberry berries. Hydrogen cyanide delivered into the body by inhalation or skin or after being consumed dissociates into cyanide ions, showing strong affinity to cations of iron in the hemoglobin molecule. This results in inhibition of an enzyme responsible for the processes of cellular respiration called cytochrome oxidase. Blocking of the enzymatic system results in interfering with the release of oxygen from the oxyhemoglobin in the tissues, and characteristic in this case bright red color of venous blood. The first symptoms of poisoning are: headache, tinnitus, shortness of breath, abnormal blood pressure and heart rate. Developing intoxication leads to coma or death (Dellagreca, 2000).

Wild elderberry is easily confused with Hebda lilac, because the two species differ only slightly by the appearance of leaves. Hebda elderberry fruit intake leads to severe poisoning despite the heat treatment since the toxins they contain do not decompose under the influence of temperature (Kremer, 1996).

\section{Common snowberry}

Common snowberry, Symphoricarpos albus, is a shrub originating from North America, imported to Europe in the nineteenth century due to its undeniable decorative properties (Fig. 4). This bush has alternate bluish green leaves, white-pink bell-shaped flowers and distinctive white berries; it is also easy for shaping. These features caused that the snowberry is often used as an ideal material for hedges and you can easily encounter it in city parks and home gardens (Seneta, 1997).

Expansiveness shown by snowberry caused its spread also to undeveloped land and wasteland due to her limited requirements for sunlight and soil qualities; although it must be mentioned that she likes limestone, alkaline mountain soils (Haberer, 2008). Snowberry is perfect for the remediation of the land, even those contaminated with oil derivatives (Fedkenheuer, 1980).

White snowberry fruit is loved by birds that contribute to spreading of this plant on wasteland. Protein-rich berries are a delicacy for sheep, cattle and wild, small mammals, which is especially important in winter because these berries do not fall down off the bushes along with first frost, thus becoming the additional source of nutrients during this difficult season for animals (Holechek, 1987).

Native Americans used the mashed fruit of snowberry as a hair shampoo and an antiseptic agent for superficial wounds and skin lesions. Flexible wood of the shrub was used to manufacture foreshafts and the brew of the bark as a remedy for venereal diseases (Halverson, 1986). It was found, however, that the consumption of snowberry fruit by humans resulted in symptoms of poisoning. Typical symptoms occurring after the consumption of snowberry fruit are vomiting, diarrhea, chills, and sometimes loss of consciousness. In extreme cases, it can also lead to collapse into a coma. Toxic effects is the result of saponins, it is macromolecular compounds from the group of glycosides (derivatives of sugar and sapogenol, which is an alcohol) (Gilbert, 1995). Saponins are able to lower water surface tension thus acting like soap; they also have antibacterial, antifungal, antiviral and protozoonicidal properties. At higher doses, however, the effect of the intake of saponin potent symptoms of gastrointestinal irritation of the mucous membranes. After entering blood, they can lower 
blood pressure and cause hemolysis of erythrocytes. In addition, saponins as antagonists to vitamin $\mathrm{D}$, causing a decline in bone mineralization. Severe poisoning results in impaired breathing.

Snowberry berries also contain calcium oxalate crystals, i.e. so called raphides. They are responsible for irritant effect that occurs after ingestion of the berries, as well as intense burning and swelling of the mucous membranes. In extreme cases, swelling of the larynx can lead to death by suffocation (Haratym, 2014).
The last group of compounds which should be mentioned is the alkaloids, especially chelidonine, a derivative of $\alpha$-phenanthrene. Its influence on the nervous system is similar to that exerted by morphine, but much weaker. In contrast to morphine, the compound does not cause, however, feelings of euphoria. Chelidonine is a compound of cytotoxic (exhibits toxicity to the cells of the body, because due to solubility in the cholesterol it penetrates cell membranes) because it inhibits mitotic cells. It is also responsible for burning sensations
Fig. 4.

Common snowberry

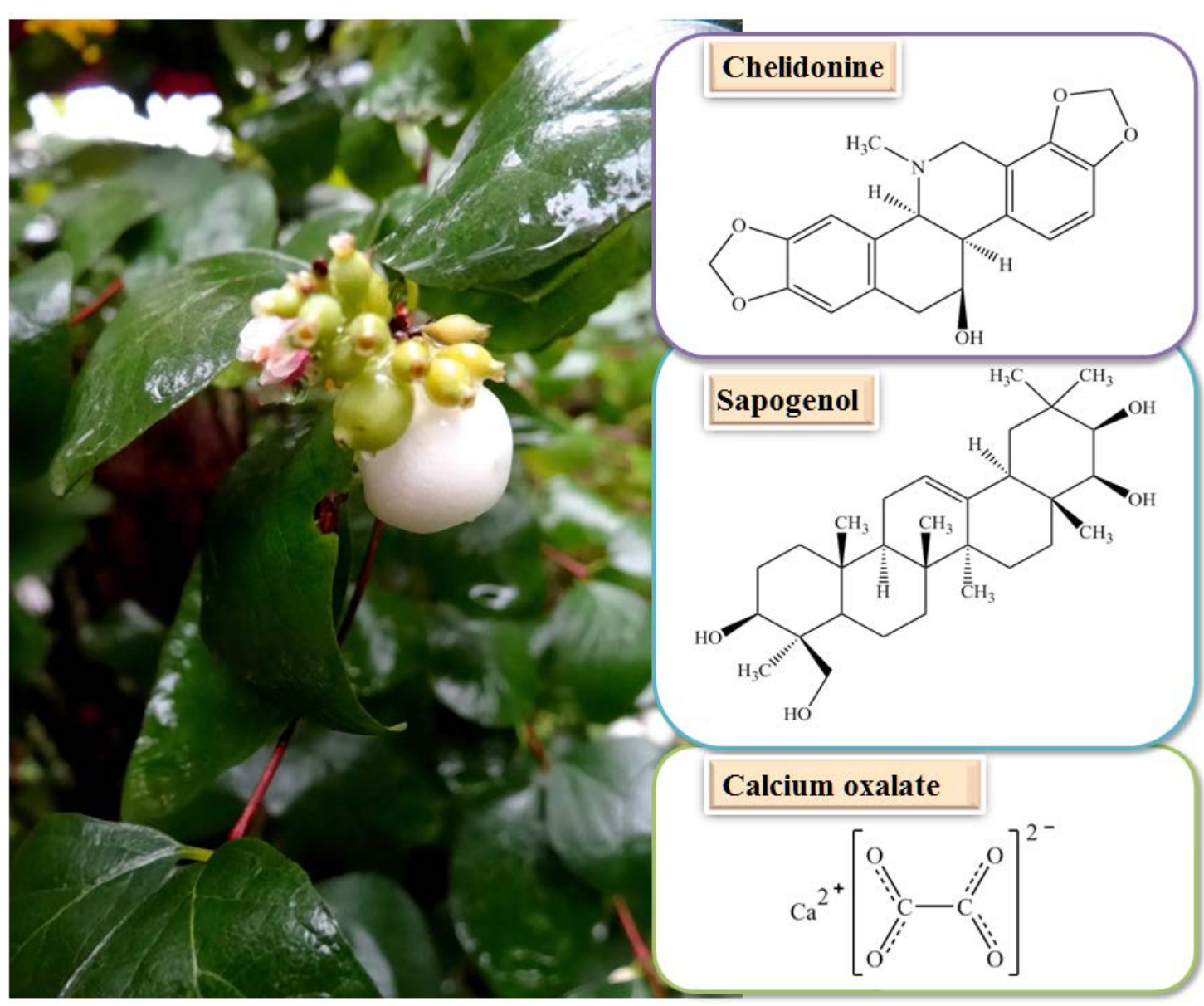

and nausea. After the consumption of berries narcotic effects can be also observed. The presence of the chelidonine in the snowberry material is scant; however, we should recall here the thought of Paracelsus - Dosis facit venerium (only the dose makes the substance not poisonous) and bear in mind different individual sensitivity in response to the toxin.

Two other alkaloids characteristic for snowberry, loganin and secologanin, belonging to irydoid glycosides, do not have toxic but only anti-inflammatory properties (Sadowska, 2004).

\section{Savin juniper}

One of the few glacial relics, dating from before the Holocene era is Juniperus sabina, popularly called savin juniper (Fig. 5). The Sabins, an ancient Italic tribe after which it took its name, used the branches of this tree as a magical artifact that protected them against unplanned pregnancy (Ziółkowska, 1988). During the Ice Age, when continetal ice sheet reached the Carpathians, savin was able to make the expansion to the south and survived there to modern times in the area of today's Pieniny on only a few positions (Hryniewiecki, 2008). Soil conditions played a major role in the acclimatization of savin: alkaline limestone substrate combined with well-permeable claystone and sandstone and volcanic rocks. Savin can be seen in its natural environment in the Pieniny National Park: in the area of the gorge of the Leśnicki Stream and Dunajec River Gorge, on such rock formations as Cukrowa Góra or Facimiecha (Mirek, 2008).

Pieniny, which used to be home to savin, now have only a few positions of its occurrence. This is the man and wasteful exploitation of savin juniper we can blame for this state. Savin juniper used to play an important role in folk medicine, where, despite its unpleasant 


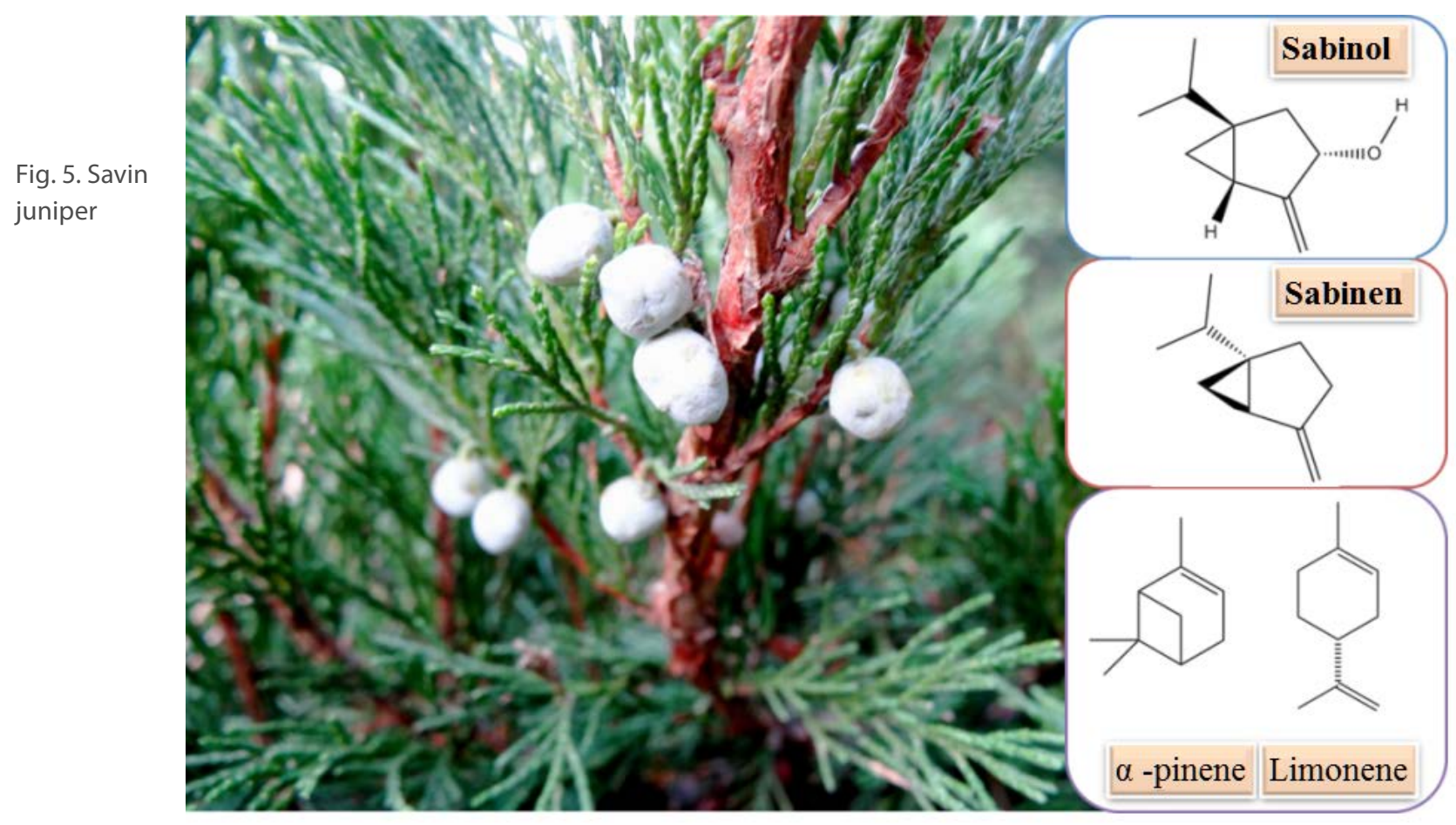

smell, was used as an abortifacient (causing high mortality rate in women), antirheumatic, diuretic, anthelminthic mean, also helpful in removing warts (Bohne, 2008). Oil from needle leaves of savin was used as an insecticide and repellent and found application in the perfume industry. Furthermore, people used to make canes savin thought to have the power to ward off domestic demons, vampires and strigoi. A similar habit of wandering with savin canes was also present in the Alps, but nothing is known about its magical connotations (Ziółkowska, 1988). The depletion of natural population of savin juniper results in entering it to the World Red Book of Endangered Species and onto the Red List of Polish Plants and Fungi as a rare and endangered species, although it is a popular and undemand- ing shrub commonly present in parks and gardens (Mirek, 2008).

Based on the $\mathrm{LD}_{50}$ parameter $\left(\mathrm{LD}_{50}\right.$ is statistically calculated median lethal dose for a specific animal species), savin juniper is classified as moderately toxic. Due to the poisonous effect of savin special care should be taken not to confuse it with juniper which is used for the production of aromatic alcohols and seasoning meat. Exposure of the crushed parts of the plant to the skin or mucous membrane brings about the irritation or inflammation which may even result in necrosis. Consumption of green parts savin leads to severe poisoning, manifested symptoms of gastrointestinal (nausea, vomiting, diarrhea, abdominal pain), renal failure and hematuria and dysfunction of the nervous system (paralysis, loss of consciousness, breathing disorders). Substances contained in savin juniper lead to congestion of the blood vessels in the abdomen and hence it is an abortifacient (Altmann, 1998). It is believed that the only 6 drops of oil obtained from savin juniper can kill an adult person within 10 hours.

Active ingredients in savin juniper essential oil are mainly monoterpenes: both $\alpha$-pinene (a compound of the characteristic odor of pine) and limonene (with intense fragrant of lemons) are widely used in the perfume industry. However, both these compounds are also highly irritant to humans and can cause allergic reactions. These substances are also responsible for the properties of insecticides and insect repellents. Isomers of cadinene and sesquiterpene present in the oil, responsible for the characteristic pungent smell of savin juniper, are not harmful to the human body. Another group of compounds which are derivatives of sabinen acid are sabinen, sabinol and sabinon. They are toxic compounds that can cause disorders of the digestive system, the nervous system, bleeding and kidney damage. The water- and alcohol soluble oil helpful in the removal of warts, can also cause necrosis of the epidermis. Sabinol is, however, a source of odor released after grinding berries or needle leaves of savin and referred to by some people as similar to the smell of cat urine (Dweck, 2009).

\section{Lily of the Valley}

Lily of the Valley, Convallaria majalis, perennial known for its small, white flowers and sweet scent, is easy to grow and has low requirements for soil (Fig. 6). It is commonly propagated vegetatively by shallowly buried rhizomes, which facilitates the creation of large colonies, rarely by seeds enclosed in a red berries (Altmann, 1998). 
Fig. 6. Lily of the Valley

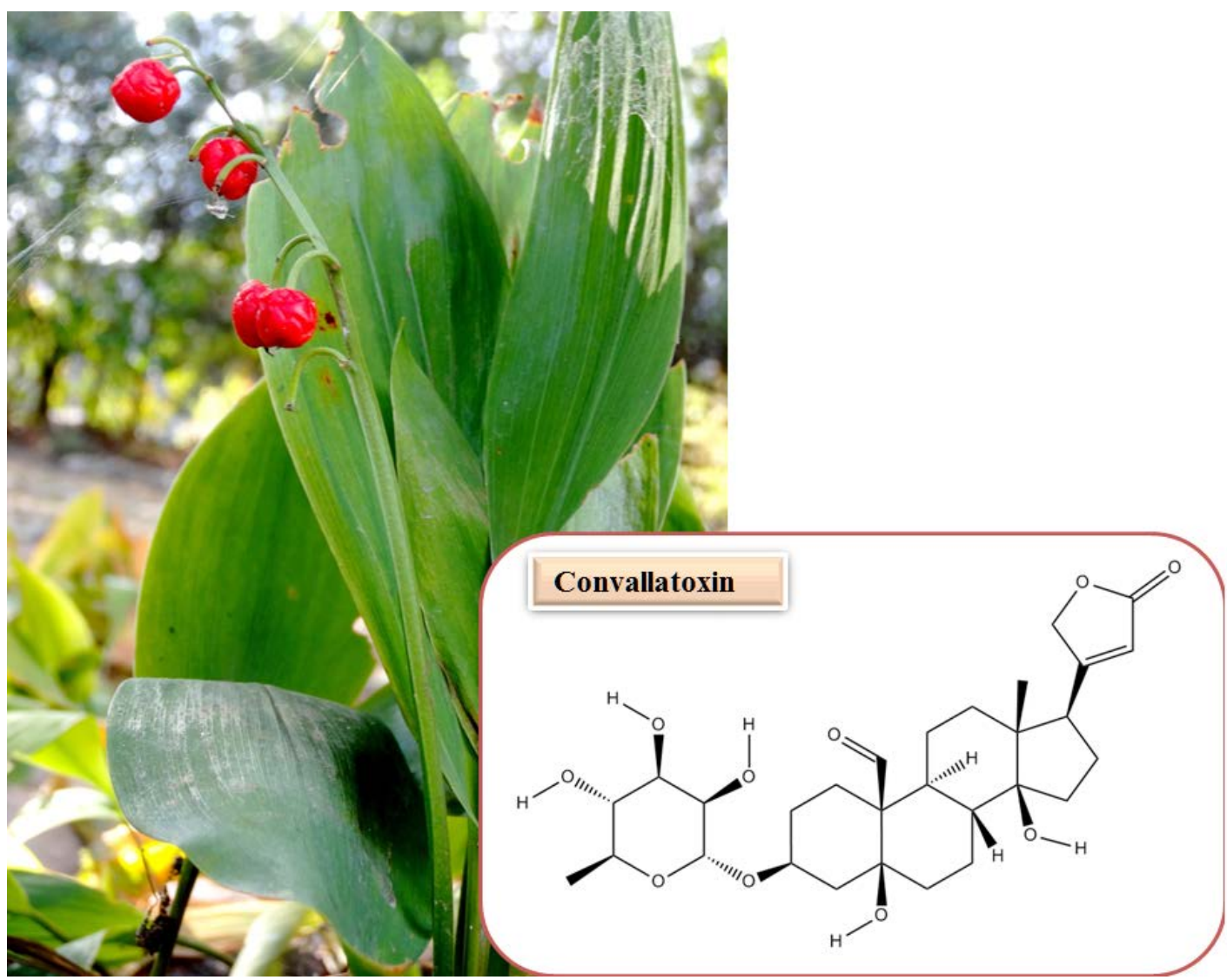

Thanks to its aesthetical properties (falling flowers and elongate leaves mentioned before) lilies of the valley have symbolized the purity of brides for centuries. In France, the first day of May is called the Fête du Muguet (Lily of the Valley Day), to commemorate the events of the sixteenth century, when the French King Charles IX got "lucky" lily of the Valley bouquet (https://visitnormandy.wordpress.com). In folk medicine, lily of the valley is known as a remedy for many diseases, e.g. heart issues or swelling. Once it was considered as a symbol of doctors.
This is due to the content of approximately 40 recognized cardiac glycosides (i.e. cardenolides) (Rumińska, 1990) of which the most important is convallatoxin. Its non-sugar part is the steroid moiety of an unsaturated lactone (Kittleson, 1998). Convallatoxin is present in the whole plant, including the berries.

Cardiac glycosides cause inhibition of sodium-potassium pump in myocardial cells, resulting in an increase in intracellular sodium and calcium ions. This in turn translates into increased strength of contraction of the heart muscle while decreasing the frequency of operation (Atkinson, 2008). This causes that the lily of the valley extracts are used to treat heart failure, cardiac or supraventricular tachycardia. The advantage of drugs based on cardenolides of lily of the Valley is that they are not cumulative (Sarva, 2011), which means they are safe for long-term use, also in elderly.

However, homemade specifics, as well as the consumption of unprocessed parts of lily of the valley, carry some risk - you cannot determine the content of active substances in the preparations made, which may result in overdosing. Poisoning begins with gastrointestinal symptoms, namely diarrhea and nausea (Yang, 2012). Then toxins affect vision (seeing yellow) (Bauman, 2006), and confusion and hallucinations occur. The overdose makes heart rate drop below 60 beats per minute (i.e. bradycardia), and in extreme cases may also result in atrial fibrillation and cardiac arrest (Altmann, 1998).

\section{Conclusion}

The world of plants is extremely rich. The beauty of plants is demonstrated in the shape of their leaves, shape and color of inflorescences, the smell they spread, and the form of fruit, often tempting and resembling those that we are used to seeing on our tables. The true mystery of the world of plants, however, lies in the chemicals contained in the plant tissues.

We do not have to go on a trip to the tropics to meet a plant which can be a threat to us. Just go to the forest, the garden or the nearby park. Exposure to a toxic substance usually occurs through the skin or by ingestion. Poisoning occurs mostly as a result of swallowing colorful berries, looking attractive to us. The observed toxic effect depends only on the content of toxic substances in the consumed plant tissue and the sensitivity of individual organism. Keep in mind that a small dose 
may have healing properties but when consumed in excess can lead to severe poisoning. What's more, each of us has an individual sensitivity to chemicals; a few innocent looking fruits can cause vomiting to one person and may be fatal to another one. So what should you do if you experience symptoms of poisoning in people around you? First of all, ensure safety for yourself and the affected person and determine whether she/he is conscious and breathing and break contact with the poisonous substance. It is also necessary to call for help and while waiting for an ambulance trying to determine what caused the poisoning. Also, do not leave the injured person until the aid arrives.

So this why it is worth checking to which species the plant picked fruit belong. Use a plant atlas or a tourist guide. You may pay high price for your mistake.

\section{References}

Altmann H (1998). Rośliny trujace i zwierzeta jadowite. Warszawa: Multico Oficyna Wydawnicza.

Atkinson KJ, Fine DM, Evans TJ, Khan S (2008). Suspected lily-ofthe-valley (Convallaria majalis) toxicosis in a dog. Journal of Veterinary Emergency and Critical Care. 18:399-403. DOI:10.1111/ j.1476-4431.2008.00325.x

Atkinson DM, Atkinson E (2002). Sambucus nigra L.. Journal of Ecology 90 (5): 895-923. DOI: 10.1046/j.1365-2745.2002.00698.x

Bauman JL, Didomenico RJ, Galanter WL (2006). Mechanisms, manifestations, and management of digoxin toxicity in the modern era. American Journal of Cardiovascular Drugs. 6:77-86.

Bohne B, Dietze P (2008). Rośliny trujace: 170 gatunków roślin ozdobnych i dziko rosnacych. Warszawa: Bellona.

Braun L, Cohen M (2015). Herbs and Natural Supplements. Elsevier Health Sciences.

Bryan-Brown T (1932). The Pharmacological actions of taxine. Journal of Pharmacy and Pharmacology. 5: 205-219.

Burda PR (1998). Zatrucia ostre grzybami i roślinami wyższymi. Warszawa: Wydawnictwo Naukowe PWN.

Daniluk J, Jurkowska G (2005). Zarys chorób wewnętrznych dla studentów pielegniarstwa. Wydawnictwo Lekarskie PZWL

Dellagreca M, Fiorentino A, Monaco P, Previtera L, Simonet AM (2000). Cyanogenic Glycosides from Sambucus Nigra. Natural
Product Letters. 14 (3): 175-182. DOI:10.1080/10575630008041228 Dweck AC (2009). Toxicology of essential oils reviewed. Personal Care. September: 65-77.

Fedkenheuer AW, Heacock HM, Lewis DL (1980). Early performance of native shrubs and trees planted on amended Athabasca oil sand tailings. Reclamation Review. 3: 47-55.

Gibbons B, Brough P (1995). Atlas roślin Europy Pótnocnej i Środkowej. Warszawa: Oficyna Wydawnicza Multico.

Gilbert OL (1995). Symphoricarpos albus (L.) S. F. Blake (S. rivularis Suksd., S. racemosus Michaux). Journal of Ecology. 83(1): 159-166. Grieve M (1931). A modern herbal. Online: http://botanical.com/botanical/mgmh/e/elderd05.html. Dostęp: 11.09.2016.

Haberer M (2008). 333 rośliny ogrodowe. Warszawa: Wydawnictwo RM.

Halverson NM (1986). Major indicator shrubs and herbs on National Forests of western Oregon and southwestern Washington. Portland, Department of Agriculture, Forest Service, Pacific Northwest Region.

Haratym W, Weryszko-Chmielewska E, Żuraw B, Tietze M (2013). Krzewy o właściwościach trujacych. Alergoprofil. 9 (4): 26-34.

Holechek JL, Berry TJ, Vavra M (1987). Grazing system influences on cattle performance on mountain range. Journal of Range Management. 40(1): 55-59.

Hryniewiecki T (2008). Drzewa i krzewy. Warszawa: MULTICO Oficyna Wydawnicza.

Kittleson MD (1998). Digitalis glycosides, In: Kittleson MD, Kienle RD. eds. Small Animal Cardiovascular Medicine, 1st edn. St. Louis: Mosby; 159-166.

Kobusiak-Prokopowicz, M., Marciniak, A., Ślusarczyk, S. et al. (2016). A suicide attempt by intoxication with Taxus baccata leaves and ultra-fast liquid chromatography-electrospray ionizationtandem mass spectrometry, analysis of patient serum and different plan samples: case report. BMC Pharmacology and Toxicology. 17: 41 . DOI:10.1186/s40360-016-0078-5.

Kremer BP (1996). Owoce leśne - jagody, orzechy, pestkowce. Warszawa: Multico.

Mazid M, Khan TA, Mohammad F, Khan T (2011). Role of secondary metabolites in defense mechanisms of plants. Biology and Medicine. 3 (2) Special Issue: 232-249.

Mirek Z, Halina Piękoś-Mirkowa H (2008). Czerwona księga Karpat Polskich. Kraków: Instytut Botaniki PAN.

Piękoś-Mirkowa H, Mirek Z (2003). Atlas roślin chronionych. Warszawa: Multico Oficyna Wydawnicza.

Rumińska A, Ożarowski A (1990). Leksykon roślin leczniczych Warszawa: Wydawnictwo Rolnicze i Leśne.

Sadowska A (2004). Rakotwórcze i trujące substancje roślinne. Warszawa: Wydawnictwo SGGW.

Sainio EL, Rantanen T, Kanerva L, et al. (2001). Ingredients and safe- ty of cellulite creams. European Journal of Dermatology. 10:596 603.

Sarwa A (2011). Wielki leksykon roślin leczniczych. Warszawa: Wydawnictwo Książka i Wiedza.

Seneta W, Dolatowski J (1997). Dendrologia. Wyd. II. Warszawa: Wydawnictwo Naukowe PWN.

Thuret-Carnahan J, Bossu JL, Feltz A, Langley K, Aunis D (1985). Effect of taxol on secretory cells: functional, morphological, and electrophysiological correlates. The Journal of Cell Biology. 100:1863-1874 Wilson CR, Sauer J-M, Hooser SB (2000). Taxines: a review of the mechanism and toxicity of yew (Taxus spp.) alkaloids. Toxicon. 39(2):175-185.

Yang EH, Shah S, Criley JM (2012). Digitalis toxicity: a fading but crucial complication to recognize. American Journal of Medicine, The. 125:337-43.

Ziółkowska M (1988). Gawędy o drzewach. Warszawa: Ludowa Współdzielnia Wydawnicza.

Websites:

ht tp://www.andersen.sdu.dk/vaerk/hersholt/ TheElderTreeMother_e.html (opublikowano: 11.08.2015. Dostęp: 29.08.2016)

https://visitnormandy.wordpress.com/2010/04/26/lily-of-thevalley-may-day-in-france (opublikowano: 26.04.2010. Dostęp: 12.10.2016) 